\title{
Development of regional foresight studies between 2000 and 2019: an overview and co-citation analysis
}

\author{
Hamed Amini ${ }^{1}$, Mohammad Saeed Jabalameli ${ }^{2 *}$ and Mohammad Hosein Ramesht ${ }^{3}$
}

\begin{abstract}
Regional foresight is one of the regional planning approaches that increase the ability to deal with uncertainty and changes. This study aims to provide an overview of regional foresight studies and domain map to evaluate their merits and defects and direct future studies in this field. For this purpose, 111 papers related to regional foresight were identified at the "Web of Science" in the period 2000 to 2019 and used as the basis for further analysis. These papers have been reviewed in various aspects. In addition, the domain map of regional foresight and its intellectual bases was drawn based on co-citation analysis of these papers and their 4194 references. The domain map includes five main clusters of research areas or intellectual bases for regional foresight: normative forecasting, participation, foresight in policy and strategy, innovation systems, and multi-level governance. Finally, the merits and defects of regional foresight studies are evaluated based on research results and some suggestions are provided for future studies.
\end{abstract}

Keywords: Regional foresight, Regional planning, Domain map, Co-citation analysis, Foresight

\section{Introduction}

To account the increasing complexity and speed of changes in the current century in terms of urban and regional policy-making, it is necessary to come up with the approaches that provide the grounds for anticipating and becoming ready to face changes. Great changes in political, social, cultural, and economic issues and their interactions, as well as inherent uncertainty involved in some of these factors, have made it difficult to anticipate the future of such changes. Although environment changes have profound effects in some regions, they still lack strong well-developed policy institutions that can cope with such changes [1]. These challenges have led to future-oriented approaches, most commonly known as "regional foresight," to enter territorial issues. Regional

\footnotetext{
* Correspondence: Jabal@ie.iust.ac.ir

${ }^{2}$ School of Industrial Engineering, Iran University of Science \& Technology,

Tehran 1684613114, Iran

Full list of author information is available at the end of the article
}

foresight is, in fact, the result of the introduction of foresight and its capabilities in territorial issues.

Various studies have been conducted on regional foresight. These studies deal with how to implement or present the achievements of regional foresight in their cases. After about 20 years from the advent of the concept of regional foresight in scientific papers, it may be the time to evaluate the course. In this regard, it is necessary to conduct an evaluation that has a comprehensive look at past research, highlights the strengths and achievements of studies of these years, and underlines shortcomings in future studies while demonstrating the orientations and roots of regional foresight studies.

The remainder of this study is organized as follows: The "Conceptual background" section is allocated to define the conceptual backgrounds. The "Methodology" section addresses the methodology of the study, especially the co-citation analysis method used in the research. The "Overview of papers" section represents an overview of key information from selected papers, briefs
Springer Open (c) The Author(s). 2021 Open Access This article is licensed under a Creative Commons Attribution 4.0 International License, which permits use, sharing, adaptation, distribution and reproduction in any medium or format, as long as you give appropriate credit to the original author(s) and the source, provide a link to the Creative Commons licence, and indicate if changes were made. The images or other third party material in this article are included in the article's Creative Commons licence, unless indicated otherwise in a credit line to the material. If material is not included in the article's Creative Commons licence and your intended use is not permitted by statutory regulation or exceeds the permitted use, you will need to obtain permission directly from the copyright holder. To view a copy of this licence, visit http://creativecommons.org/licenses/by/4.0/. 


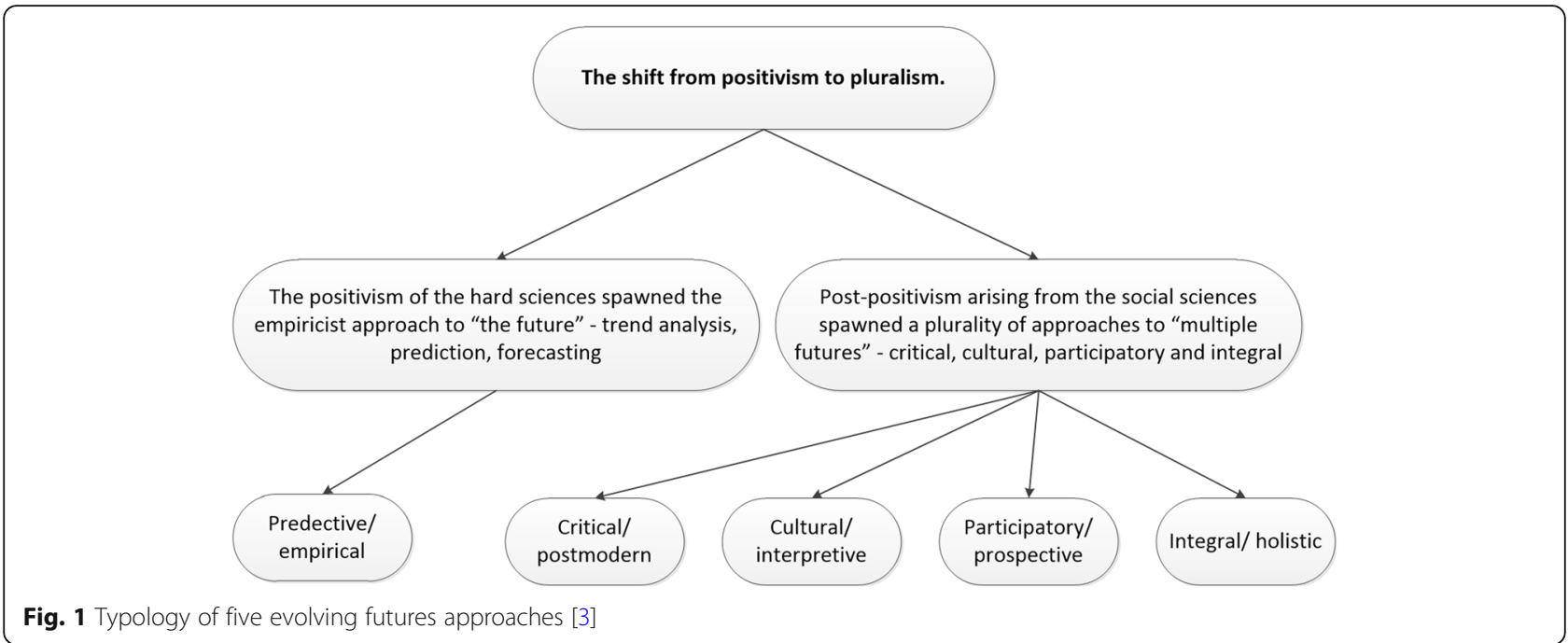

about publications, active authors, countries, keywords, journals, and most popular methods and issues. The "Results of co-citation analysis" section presents the result of co-citation analysis. In this section, also, domain map of regional foresight and the description of clusters or intellectual bases are provided. Eventually, the "Conclusions" section provides the concluding remarks, based on the results of the analysis, the strengths and weaknesses of regional foresight studies, and recommendations for further studies.

\section{Conceptual background}

Foresight is one of the various names used for referring to the field of studying future. Most commonly used names in this field are futures studies, and foresight. The concepts of futures studies (also called futures research) and foresight are close to each other. Both of these concepts use the same theories and methodology. The main difference is that foresight is doing, using, and interacting, while futures studies are more science-dependent [2]. As shown in Fig. 1, the Futures approaches have shifted over time from positivist to pluralist approaches [3].
FOREN ${ }^{1}$ has described "Foresight is a systematic, participatory process that involves gathering intelligence, building visions for a medium/long-term future, informing present-day decisions, mobilizing joint actions" (p. 311) [4]. As outlined in the definition, it can be used at various levels and topics. For example, the subject of foresight can be individuals, organizations, societies, regions, countries, continents, planets, and even issues such as technology, environmental challenges, and humanity.

Regional planning issues are to be well suited to the participative and vision-building foresight approaches. Stronger links between regional-based actors, the immediacy, and sensitivity of people to variations in their region, and a heightened level of awareness and commitment to the community should all make such approaches valuable in regional settings [4]. The name that has been used for foresight in territorial level over the past 20 years is "regional foresight."

Regional foresight means applying foresight methods for anticipation, participation, networking, vision, and action at smaller territorial scales where proximity factors become more critical. This process has five main components [5]:

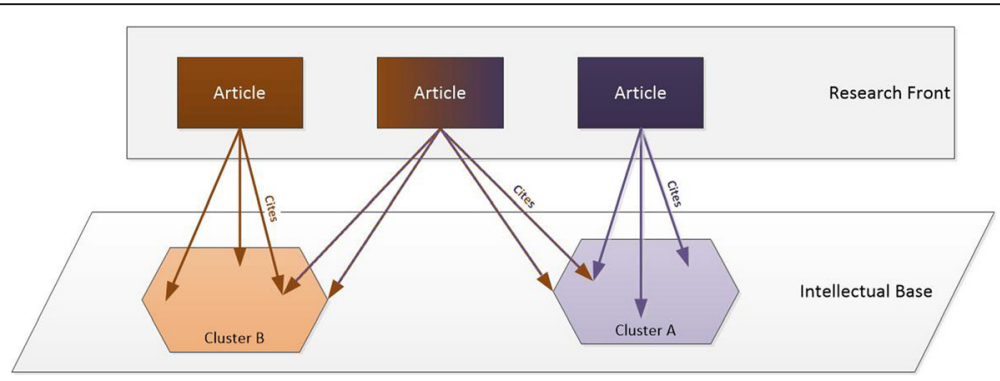

Fig. 2 The conceptual model of CiteSpace II [6] 


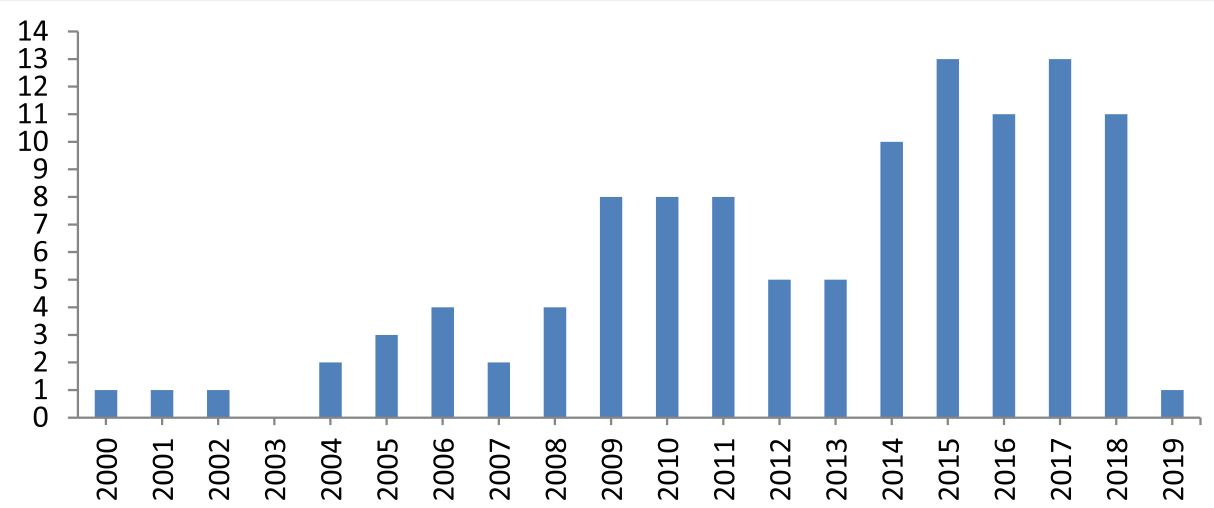

Fig. 3 Number of regional foresight papers published between 2000 and 2019

(1) Organized anticipation and projection of long-term social, economic, and technological developments and needs

(2) Interactive and participative methods of exploratory debate, analysis, and study that involve a wide variety of stakeholders

(3) Interactive approaches that involve new social networks

(4) A guiding strategic vision to which a sense of commitment can be shared

(5) The shared vision is not to be a utopia; there has to be explicit recognition and explication of the implications for the present-day decisions and actions.

"Region" is an important term in the definition of regional foresight. Region means territories that have the following two features: geographical proximity and limited spatial range. Rural communities, town/city/historical regions, regions with specific economic activity/ cultural identity, and political regions (autonomies, counties, and provinces), as well, can be covered by the term region.

\section{Methodology}

In order to achieve the goals of evaluating past research and leading future research in the field of regional foresight, four preliminary steps are considered for this research: (1) sampling and reviewing the related studies, (2) thematic analysis of basic attributes of studies to discover an overview of them, (3) co-citation analysis for discovering the domain map of regional foresight and its intellectual bases, and (4) assessing the past studies and giving recommendations for future research.

Due to the emergence of foresight and regional foresight studies, the sampling of studies was performed using the director of Web of Science without any time

\footnotetext{
${ }^{1}$ Foresight for regional development network
}

limitations. After reviewing 200 cases and removing items that appeared merely because of verbal similarity in the results, 111 valid papers were selected for the subsequent analysis.

The basic attributes of the articles were identified through the study of selected articles and thematic analysis in various dimensions. Results are presented as an overview of regional foresight studies in the "Overview of papers" section.

Then, an attempt was made to implement co-citation analysis in the field of regional foresight with CiteSpace Software. The general approach for detecting and visualizing the emerging trends and transient patterns in scientific literature is the basis for the design of this software.

In the field of "Information Science," a specialty is conceptualized and visualized as a time-variant duality between two fundamental concepts. These concepts are "research fronts" and "intellectual bases." The former is defined as an emergent and transient grouping of concepts and underlying research issues and the latter-the intellectual bases of a research front-is its citation and co-citation footprints in the scientific literature, which is an evolving network of scientific publications cited by research-front concepts (Fig. 2) [6].

The co-citation analysis performed using CiteSpace software can greatly enhance the speed and precision of the literature review. Moreover, information from the intellectual bases of the subject under review by the references of all articles is presented in an illustrative way, another achievement that will work with this method.

However, despite these benefits, there are some issues that make it hard to work with this methodology. Co-citation analysis is largely the function of the initial articles as an input, and sometimes with the choice of some wrong articles in the input section, the results are subject to many changes and deviations. 


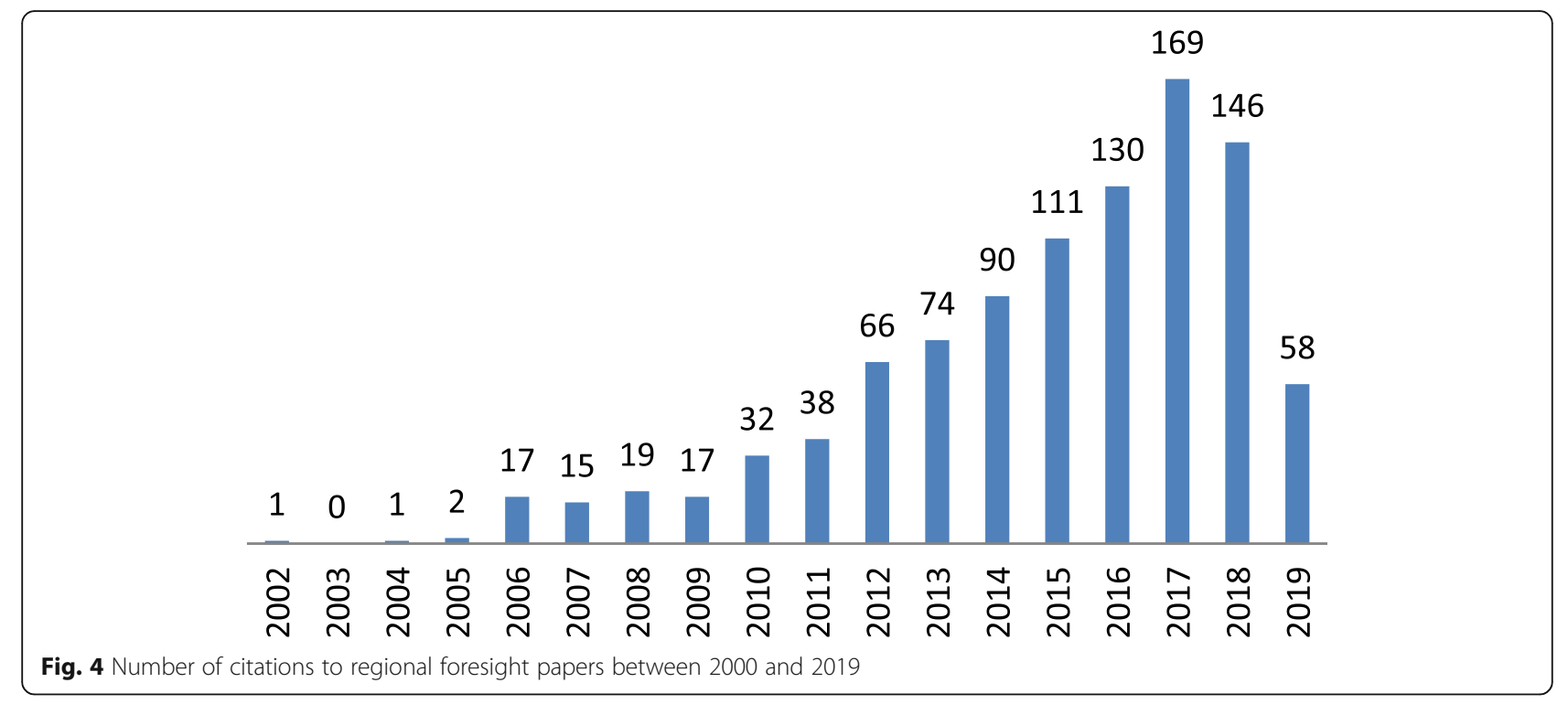

Fig. 4 Number of citations to regional foresight papers between 2000 and 2019

Table 1 Regional foresight authors active between 2000 and 2019

\begin{tabular}{|c|c|}
\hline Author & No-papers \\
\hline Ropuszynska-Surma E & 5 \\
\hline Kononiuk A & 4 \\
\hline Uotila T & 4 \\
\hline Weglarz M & 4 \\
\hline Eames M & 3 \\
\hline Konnola T & 3 \\
\hline Rinaudo JD & 3 \\
\hline Stormer E & 3 \\
\hline Truffer B & 3 \\
\hline Wylomanska A & 3 \\
\hline Ahlqvist T & 2 \\
\hline Capello R & 2 \\
\hline Roveda C & 2 \\
\hline Vecchiato R & 2 \\
\hline Caragliu A & 2 \\
\hline Dixon $T$ & 2 \\
\hline Ejdys J & 2 \\
\hline Graveline N & 2 \\
\hline Harmaakorpi V & 2 \\
\hline Hunt M & 2 \\
\hline Kaivo-Oja J & 2 \\
\hline Leclerc G & 2 \\
\hline Maurer M & 2 \\
\hline Melkas H & 2 \\
\hline Miles I & 2 \\
\hline Stratigea A & 2 \\
\hline Sacio-Szymanska A & 2 \\
\hline Rudskaia I & 2 \\
\hline Hunt M & 2 \\
\hline Saritas $\mathrm{O}$ & 2 \\
\hline
\end{tabular}

Overview of papers

Since the objective of this paper is to present a comprehensive literature review on "Regional foresight," which is an emerging knowledge, no time limits have been considered in collecting the relevant papers. While searching in the "Web of Science," 111 related papers were found from 2000 to 2019. Software studies showed that the selected papers had 4194 references, which were used for analyzing and studying the status of "Regional foresight."

\section{Number of papers published and cited on regional foresight}

Next, the status of regional foresight is studied and analyzed considering different criteria. The number of regional foresight papers published between 2000 and 2019 is shown in Fig. 3 and the annual number of citations to regional foresight papers is presented in Fig. 4. Statistics of this part are indicative of regional foresight studies with a growing trend during 2000-2019.

The growing number of citations to regional foresight articles also indicates that this area is transforming from an emerging knowledge front into a referenced domain.

\section{Regional foresight authors}

In this section, well-known regional foresight authors are introduced. Authors' names and the number of their papers are shown in Table 1. Also, Fig. 5 shows authors' names and collaborations they have had with other authors. In this figure, thicker connecting lines mean more cooperation among the authors and bigger fonts means the author has more papers in this field. 

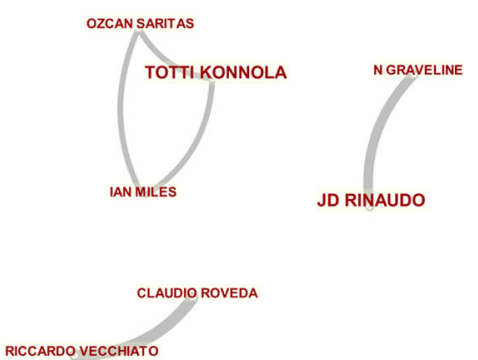
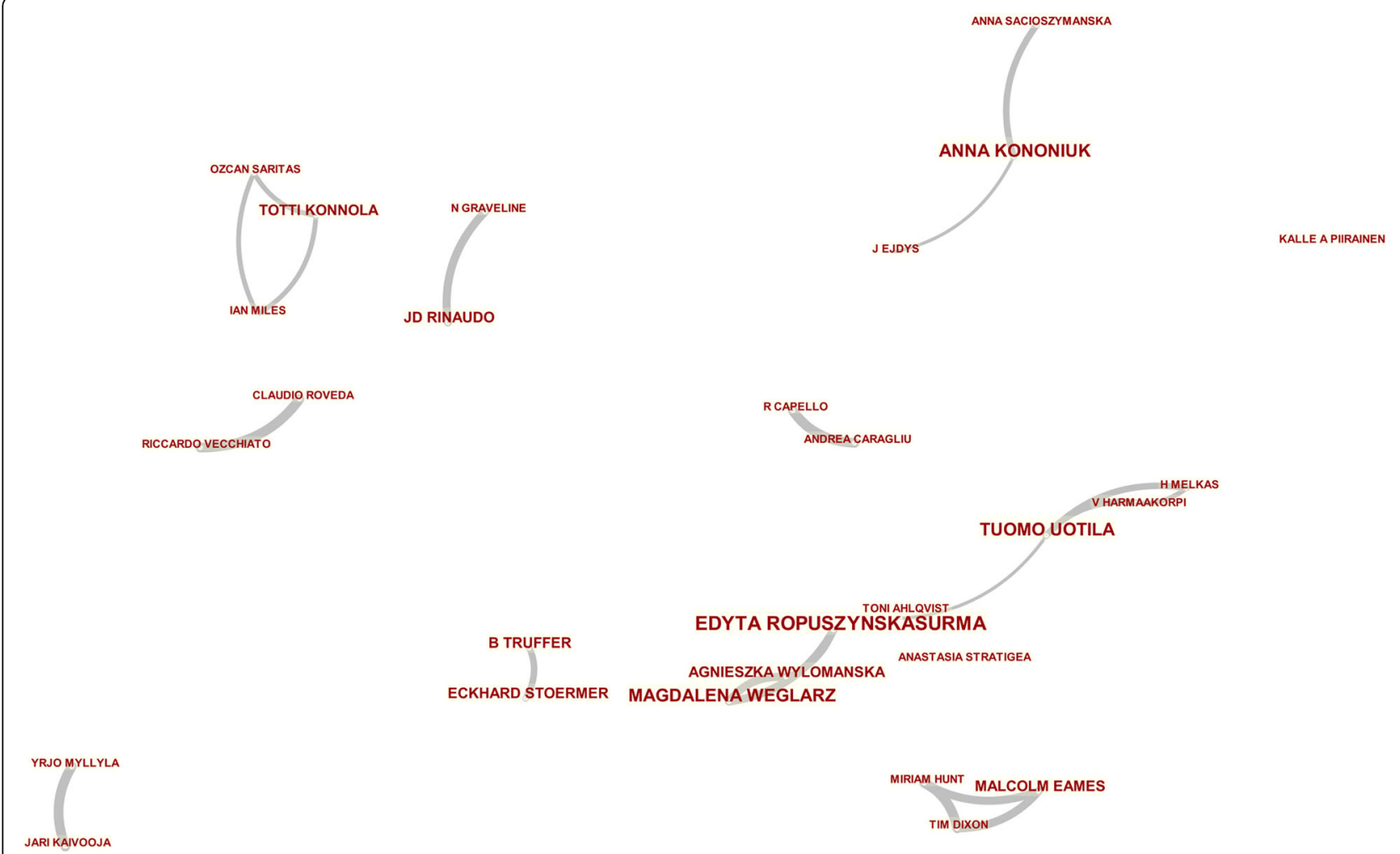

Fig. 5 Active authors and their collaborations between 2000 and 2019

Table 2 Number of regional foresight papers of different countries published during 2000-2019

\begin{tabular}{ll}
\hline No. & Country \\
\hline 15 & Finland \\
12 & Poland \\
12 & England \\
10 & Russia \\
9 & France \\
9 & Italy \\
7 & Spain \\
7 & Switzerland \\
6 & USA \\
5 & Germany \\
5 & Australia \\
4 & Austria \\
4 & Wales \\
3 & Denmark \\
3 & Norway \\
3 & Canada \\
2 & Sweden \\
2 & Belgium \\
2 & Brazil \\
2 & Greece \\
2 & Hungary \\
2 & Netherlands \\
2 & Thailand \\
\hline
\end{tabular}

\section{Active countries in regional foresight research}

In this section, countries with the highest number of regional foresight researches are introduced in the order of their contributions. The country name and its number of papers published during 2000-2019 are presented in Table 2. As can be seen, Finland, England, Poland, France, Russia, Italy, Spain, Switzerland, and the USA are the leading countries in this regard, in the order of their appurtenance. Figure 6 presents the share of countries in published papers.

The results suggest that most regional foresight studies are conducted in Europe, probably due to the limited size of most countries in this continent and the need for joint planning of neighboring territories for development. Furthermore, countries with large terrestrial zones, such as the USA and Russia, have been pursuing regional foresight because of their territorial diversity within their country.

\section{Active universities and institutes in regional foresight}

Universities and institutes active in regional foresight are presented in Table 3. The results of this section also demonstrate the dominance of European institutions and universities in regional foresight studies. 


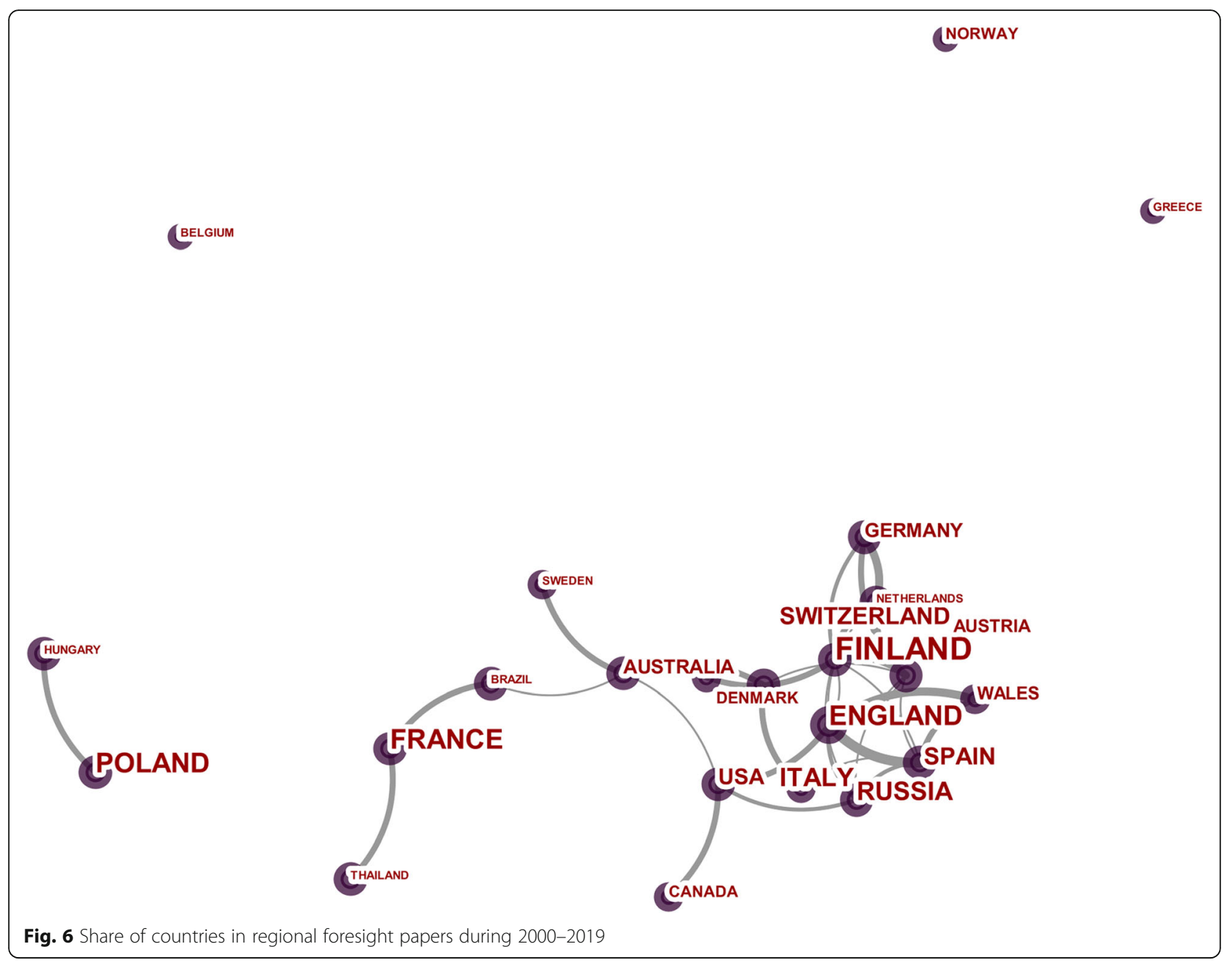

\section{Keywords}

Keywords/phrases are important tools in every research area that help researchers to have access to papers, books, and research works related to their field of expertise. Figure 7 shows the most frequent keywords in this area. Words such as foresight, management, policy, future, and scenario are the main items in Table 4.

Table 3 Number of universities and institutes papers in regional foresight

\begin{tabular}{ll}
\hline No. & Universities and institutes \\
\hline 6 & Bialystok University of Technology \\
5 & Lappeenranta University of Technology \\
5 & University of Manchester \\
4 & Institut National de la Recherche Agronomique Inra \\
4 & CIRAD Agricultural Research for Development \\
4 & Polytechnic University of Milan \\
\hline
\end{tabular}

Keywords present the proximity of futures studies concepts policy-making and sustainable development in regional foresight studies.

\section{Active journals in regional foresight}

Relevant journals, as well, are an important issue for researchers by showing which journal has published most of the related papers. Table 5 presents the number of papers published in each journal. As can be seen, $F u$ tures, Technological Forecast and Social Changes, and European Journal of Futures Research have the highest frequency in the table.

This list is a good reference for finding similar studies and subsequent publications by researchers in the field of regional foresight.

\section{The categories of regional foresight}

Another issue studied in the selected papers is the category of their case studies. The results are shown in Table 6 and Fig. 8. As can be noticed, most of these papers have addressed subject such as "urban planning," 
climate_change

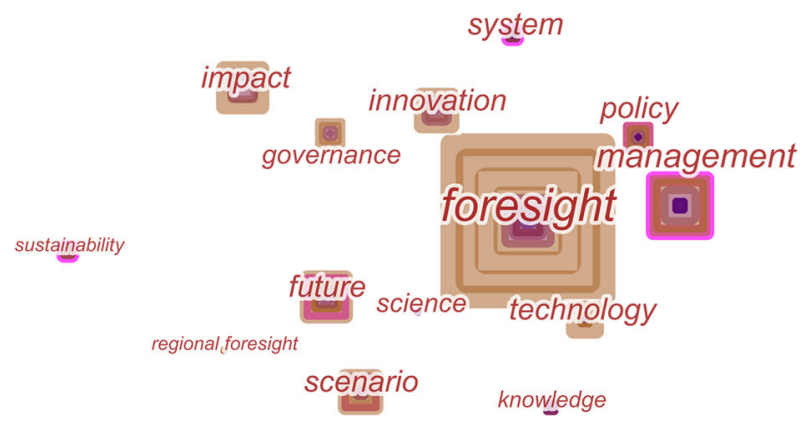

participation

technology foresight

Fig. 7 High-frequency keywords in regional foresight papers

"science and technology," "Economic development," and "industry."

The multiplicity of articles with topics in the city, village, and region, compared to articles focusing on specific subject, indicates that researchers prefer to focus on multiple subjects in the regions rather than concentrating on a topic. However, this variety of subjects also points to prioritizing issues with respect to the characteristics of the land under consideration.

Table 4 Frequency of the keywords in regional foresight papers

\begin{tabular}{ll}
\hline 38 & Foresight \\
\hline 15 & Management \\
26 & Future \\
12 & Policy \\
12 & Scenario \\
11 & System \\
10 & Innovation \\
9 & Impact \\
9 & Technology \\
8 & Governance \\
7 & Science \\
6 & Climate change \\
6 & Regional foresight \\
5 & Knowledge \\
5 & Corporate foresight \\
5 & Technology foresight \\
5 & Participation \\
\hline
\end{tabular}

High-frequency tools and methods

Studying the selected papers through well-known foresight methods provided a basis for the identification of high-frequency methods used in the related studies. These studies are illustrated in Fig. 9.

In addition to modeling, which outlines how regional foresight is implemented, scenario planning has been the most commonly used tool for studies. This tool takes regional planning out of certainty and recognizes future uncertainty in the regions.

\section{Results of co-citation analysis}

This section examines two issues by analyzing the cocitation of regional foresight papers: (1) the status of journals is analyzed by the co-citation analysis of their articles and (2) the intellectual bases of regional foresight.

\section{Co-citation analysis of journals}

In this section, co-citation analysis of the Journals is performed based on regional foresight papers and their references. Table 7 and Fig. 10 present the number of citations and centrality of each journal in the field of regional foresight, respectively. As shown in Table 7, Futures and Technological Forecasting and Social Change have been cited most frequently. Research Policy and Regional Studies Journal have the most centrality in the co-citation map of journals.

The centrality of a node is a graph-theoretical property that quantifies the importance of the node's position in a network. It measures the percentage of the number of shortest paths in a network to which a given node 
Table 5 Shares of journals from regional foresight papers

\begin{tabular}{ll}
\hline Papers & Journals \\
\hline 16 & 1.1. Futures \\
12 & 1.2. Technological Forecasting and Social Change \\
5 & 1.3. European Journal of Futures Research \\
4 & 1.4. European Planning Studies \\
4 & 1.5. Foresight \\
3 & 1.6. Rynek Energii \\
4 & 1.7. Technology Analysis Strategic Management \\
2 & 1.8. Geoforum \\
2 & 1.9. International Journal of Technology Management \\
2 & 1.10. Procedia Engineering \\
2 & 1.11. Regional Environmental Change \\
\hline
\end{tabular}

belongs. Nodes with high-betweenness centrality tend to be found in paths connecting different clusters.

\section{Clustering the intellectual bases of regional foresight}

In this section, co-citation analysis of the relevant researches is carried out based on a review of the references (4181 papers) of the 111 selected papers. The analysis results are depicted under 5 clusters (Fig. 11) and named (Table 8) considering high-cited papers in each cluster and are explained briefly in the following subdivisions.

Five clusters identified in the intellectual base of regional foresight studies show that the foundations of this emerging field of knowledge are based on these concepts: visioning, participation, innovation systems, foresight applications in policy-making and management, and multi-level governance.

Table 6 Number and paper references devoted to various subjects in the selected papers

\begin{tabular}{llll}
\hline Number & Papers & Subject & No. \\
\hline 24 & {$[5,7-29]$} & Region, city, village & 1 \\
22 & {$[30-50]$} & Science and technology & 2 \\
12 & {$[51-62]$} & Industry & 3 \\
11 & {$[63-73]$} & Economic development & 4 \\
9 & {$[74-82]$} & Energy & 5 \\
8 & {$[83-91]$} & Environment and climate change & 6 \\
4 & {$[92-95]$} & Water & 7 \\
4 & {$[96-99]$} & Terrorism & 8 \\
3 & {$[100-102]$} & Food & 9 \\
3 & {$[103-106]$} & Land use & 10 \\
2 & {$[107,108]$} & Crisis management & 11 \\
9 & $\ldots$ & Others & 12 \\
\hline
\end{tabular}

\section{Cluster 1: normative forecasting}

This cluster, compiled during 2006-2012, focuses on the importance of drawing a vision for addressing regional and environmental issues, as well as on the need for active participation of people in this process. For instance, visions of "development of hydrogen energy" [109], "urban development" [110], and "carbon pollutants" [111] have been outlined thematically. Some other papers in this cluster have addressed the potential and importance of visioning and backcasting methodologies in solving issues such as urban planning [112, 113] and sustainable development [114].

\section{Cluster 2: participation}

This cluster of papers that started from the year 2000 has addressed critical elements in the foresight process. Some papers consider participation as a necessity for new foresight and strategic planning models $[115,116]$. Some articles also point to the vital importance of "participation" in regional development and regional innovation systems [70, 117].

\section{Cluster 3: foresight in policy and strategy}

This cluster focuses on the advantages of using foresight in strategic management and policy-making. A better understanding of changes, improving response to changes, influencing other actors, enhancing organizational learning, understanding new businesses [118], developing innovative options, and improving the quality of innovation projects [119] are foresight capabilities for firm-level management.

Moreover, on a sectoral and national level, foresight is a tool for policy-making [120-122]. This tool can help understand discontinuities, increase participation, address long-term issues [120], avoid lock-in of business clusters by networking [52], and enhance innovation and learning [123]. Moreover, it also helps the process of formulation and implementation of policies by generating insights regarding the dynamics of change and building a common awareness [122].

\section{Cluster 4: innovation systems}

This cluster of studies (being published since 2011) focuses on interactions between regional foresight and innovation systems; some of them focuses on how innovation affects foresight [124] while others emphasize the effects of foresight on innovation systems [125]. At last, some of these cluster papers discuss the coevolution of these two knowledge areas [126].

\section{Cluster 5: multi-level governance}

The fifth and last cluster of regional foresight papers is related to studies on the role of foresight in multi-actor and multi-level governance at the regional level. Some of 


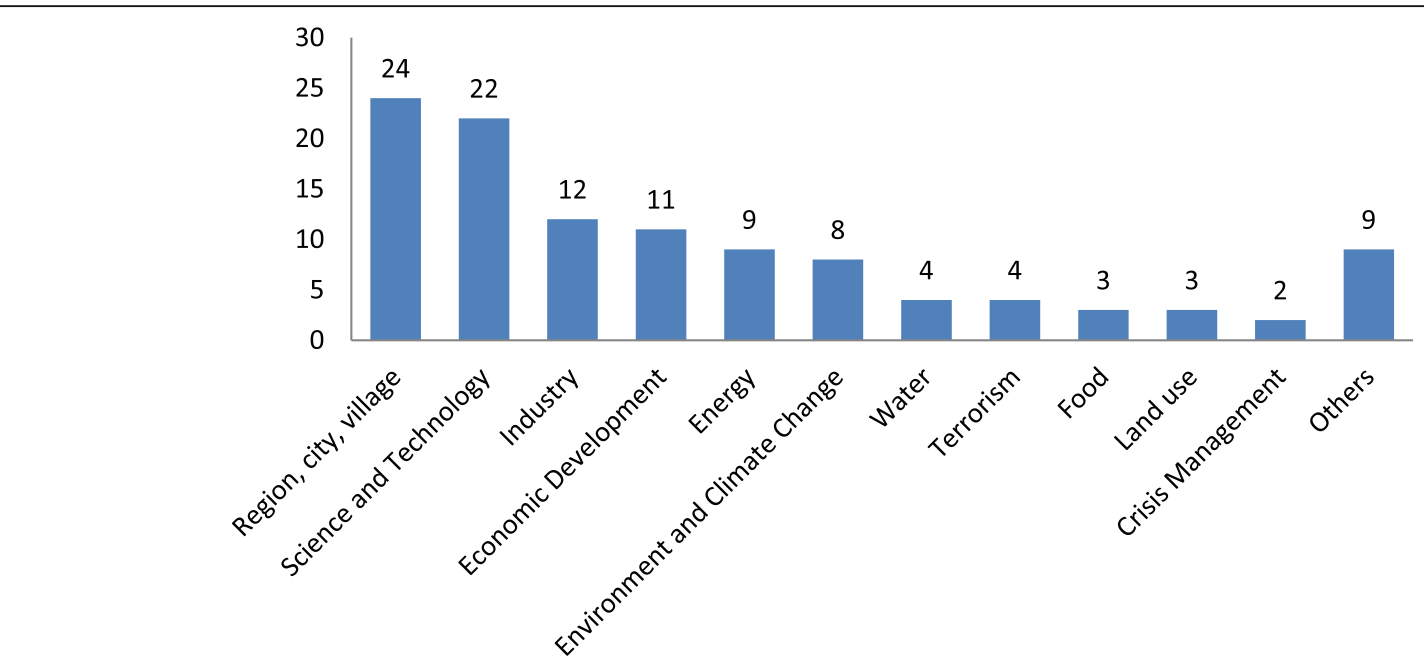

Fig. 8 Number of papers devoted to different subjects in the selected papers

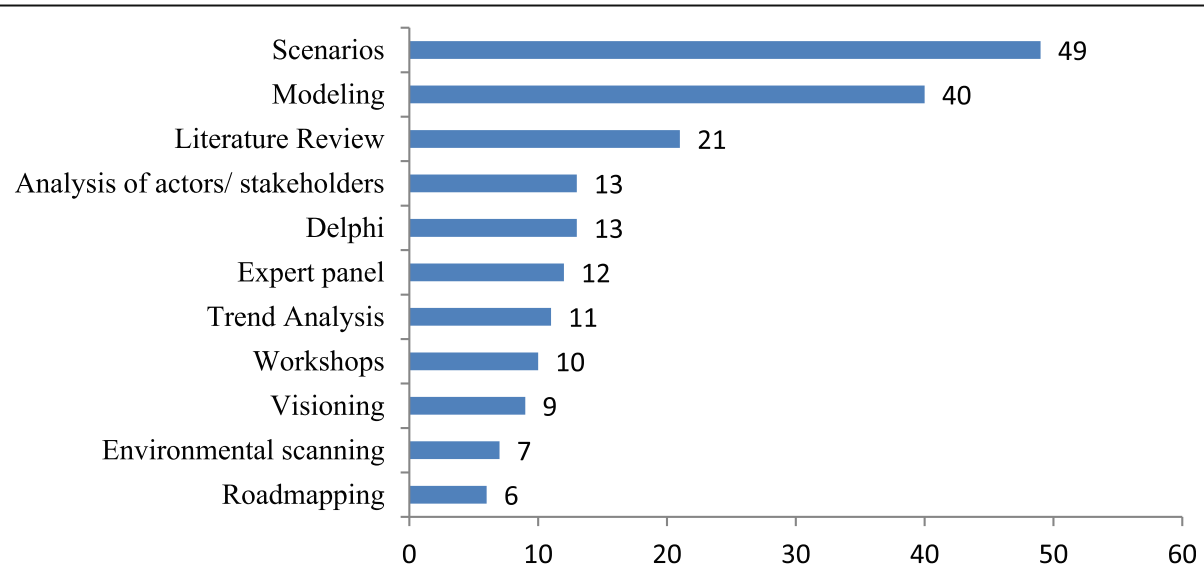

Fig. 9 Number of methods frequently used in the selected papers

Table 7 Citation and centrality of journals in co-citation map of journals

\begin{tabular}{|c|c|c|}
\hline Citation & Centrality & Journal name \\
\hline 69 & 0.01 & 1.12. Futures \\
\hline 53 & 0.03 & 1.13. Technological Forecasting and Social Change \\
\hline 29 & 0.02 & 1.14. Foresight \\
\hline 28 & 0.46 & 1.15. Research Policy \\
\hline 21 & 0.02 & 1.16. Technology Analysis and Strategic Management \\
\hline 16 & 0.00 & 1.17. Thesis \\
\hline 15 & 0.06 & 1.18. Harvard Business Review \\
\hline 15 & 0.07 & 1.19. HDB Technology Foresight \\
\hline 14 & 0.01 & 1.20. Land Use Policy \\
\hline 14 & 0.04 & 1.21. Journal of Forecasting \\
\hline 13 & 0.09 & 1.22. Energy Policy \\
\hline 13 & 0.01 & 1.23. European Planning Studies \\
\hline 13 & 0.35 & 1.24. Regional Studies Journal \\
\hline 12 & 0.01 & 1.25. Ecological Economics Journal \\
\hline 12 & 0.07 & 1.26. Global Environmental Change Journal \\
\hline 12 & 0.00 & 1.27. Long Range Planning Journal \\
\hline 12 & 0.11 & 1.28. Strategic Management Journal \\
\hline
\end{tabular}




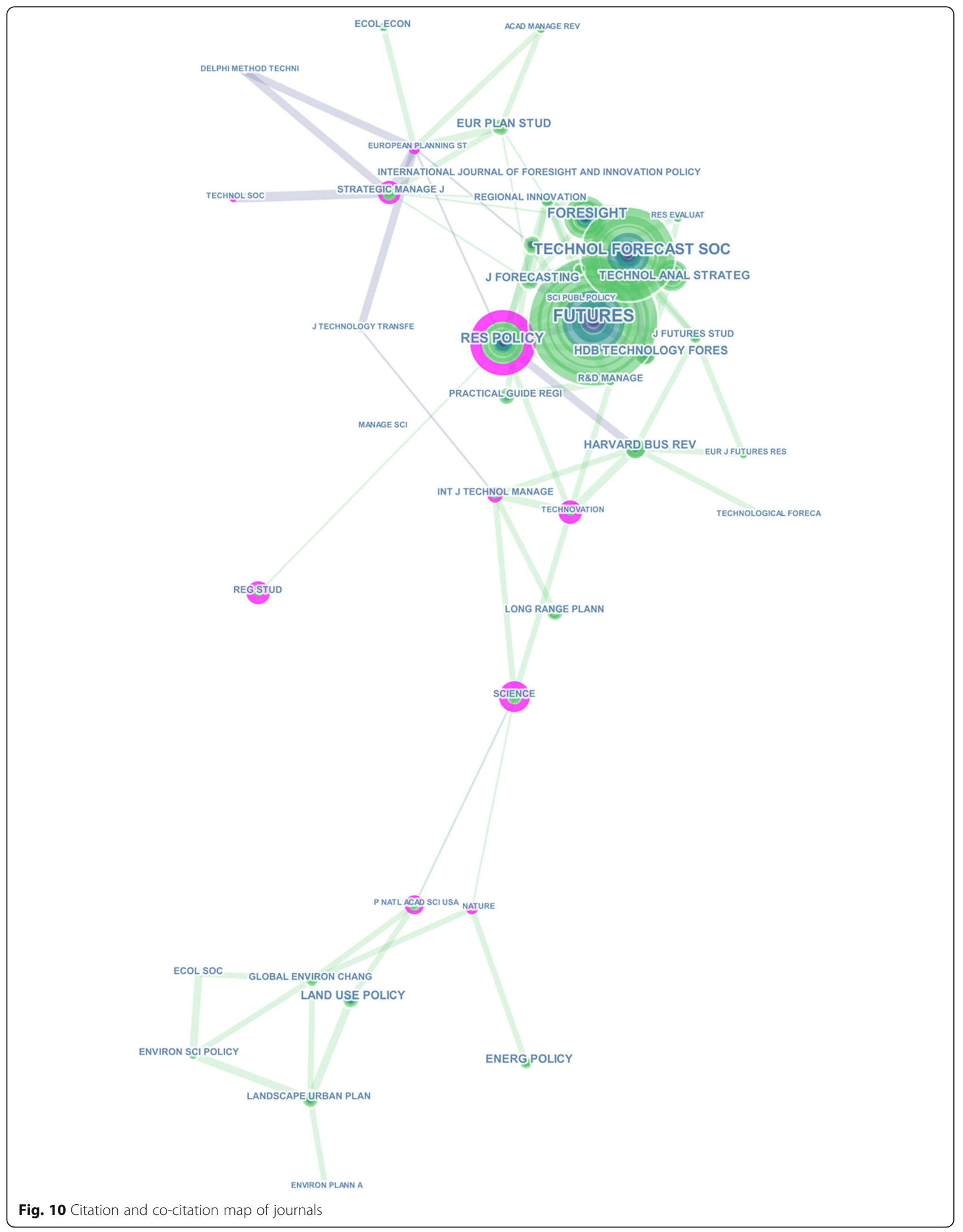



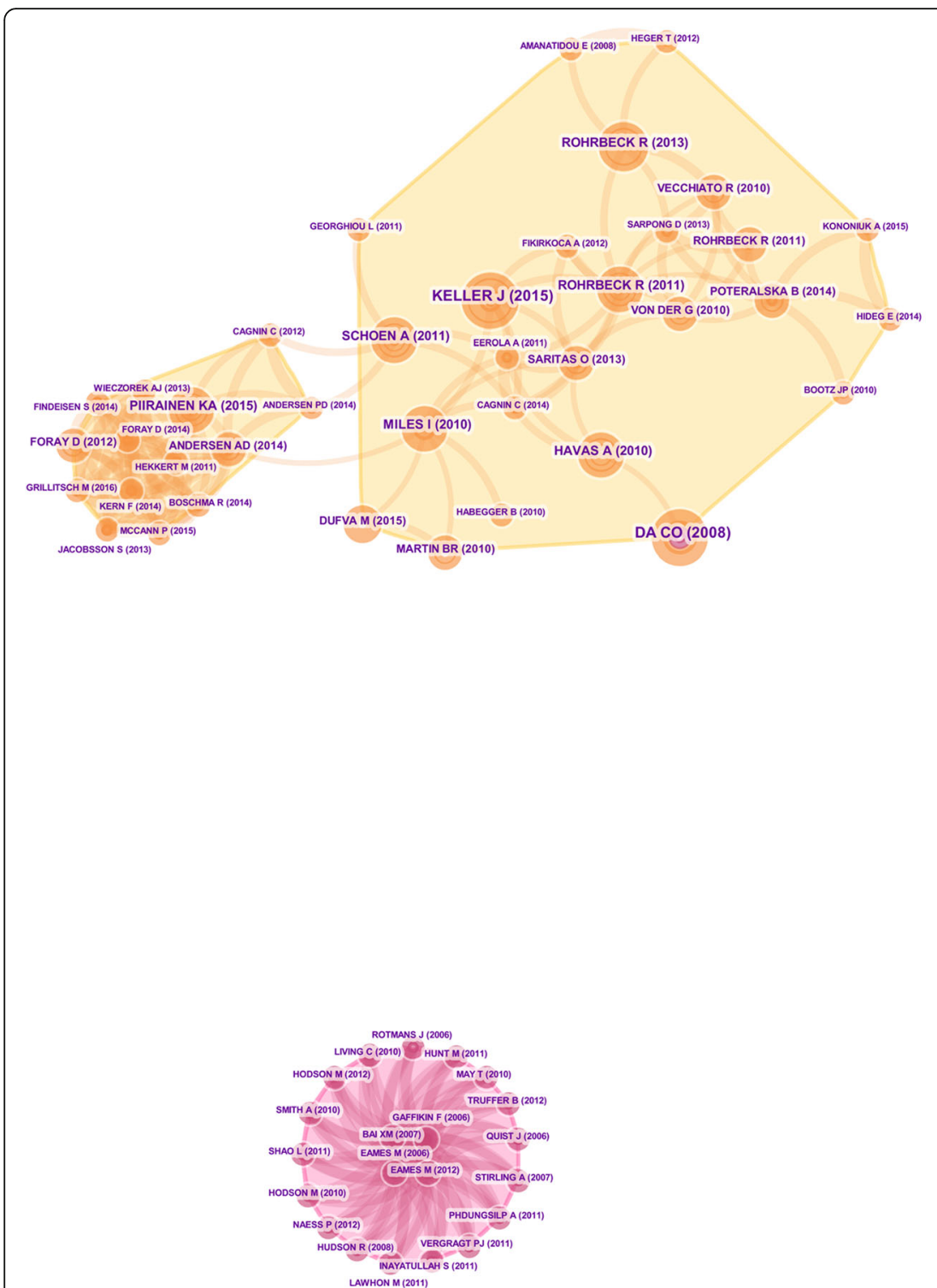

Fig. 11 The intellectual base of regional foresight studies based on co-citation analysis

the papers focus on the actors' roles at different levels in regional foresight processes $[5,127]$. Some papers discuss the importance of coordination between regional policies and upper hierarchical levels [128], while some

Table 8 Regional foresight intellectual bases based on cocitation analysis

\begin{tabular}{ll}
\hline Cluster No. & Cluster name \\
\hline 1 & Normative forecasting \\
2 & Participation \\
3 & Foresight in policy and strategy \\
4 & Innovation systems \\
5 & Multi-level governance \\
\hline
\end{tabular}

others show the results of regional foresight studies in different countries [129].

\section{Conclusions}

The present research is based on the analysis of 111 regional foresight papers from 2000 to 2109 and their references. The obtained results show that regional foresight is still an emerging field, despite the increased publication and citations over the past years. The keywords used in the articles indicate the close proximity of the field of regional foresight with the futures studies concepts, policy-making, and sustainable development.

Most of these studies are conducted within continental Europe. This seems to be due to the relative smallness of European countries and the division of a geographic 
region between several countries. In the same vein, active institutes and journals in this area are mainly located in Europe. Besides, regional foresight has been used in vast countries such as the USA. Such vastness and diversity have encouraged conducting regional foresight studies in these countries.

The multiplicity of articles with topics in the city, village, and region indicates that researchers prefer to focus on multiple subjects in the regions. Consequently, in each region, the focus of the issues should be determined according to the priorities of the region. Of the available tools, the scenario planning that represents the uncertainty in the future of the land has been most used.

As stated in the text of the article, five intellectual bases of regional foresight researches are normative forecasting and visioning, participation, foresight in policy and strategy, innovation, and multi-level governance. These categories point to a number of aspects that regional models and studies of regional prospecting should focus on, regional stakeholder participation, the creation of a shared stakeholder perspective, innovation, and a long-term perspective on planning and policy-making while paying attention to different levels of planning at different levels.

Regional foresight studies have had significant merits to date. Attention to the topic of innovation in various formats such as open innovation, social innovation or regional innovation, attention to the need for cross-level translation of programs and scenarios at different geographical/governance levels, emphasis on stakeholder participation, and the application of different approaches for analyzing their views, and the high number of cases in these studies are all promising points for conducting a set of studies on regional foresight.

However, despite these merits, there are some defects in this study that may be considered in future works. The lack of paradigmatic discussions and the focus on tools and methods are one of these defects. Moreover, these studies often do not use deeper analysis tools such as layer analysis of causes. Another shortcoming that appears in regional foresight studies is the lack of attention to the historical analysis of regional issues. Ultimately, the lack of proper assessment models in developed models for regional foresight is another issue that must be further addressed in the future.

\section{Acknowledgements}

Not applicable.

\section{Authors' contributions}

HA and MSJ conceived of the research idea. HA conducts the research methods and performed the computations. MSJ and MHR verified the analytical methods and encouraged HA to investigate and supervised the findings of this work. All authors discussed the results and contributed to the final manuscript. The authors read and approved the final manuscript.

\section{Authors' information}

Hamed Amini is a Ph.D. candidate in the field of regional foresight, Mohammad Saeed Jabalameli is Full Professor with a specialized field of land use planning, and Hosein Ramesht is Full Professor with a specialized field of Natural Geography and Geomorphology.

Funding

Not applicable.

Availability of data and materials

Not applicable.

\section{Declarations}

Ethics approval and consent to participate

Not applicable.

Consent for publication

Not applicable.

\section{Competing interests}

I can confirm that the manuscript has been read and approved by all named authors. The authors declare no competing interests.

\section{Author details}

${ }^{1}$ School of management, economics and progress engineering, Iran University of Science and Technology, Tehran, Iran. ${ }^{2}$ School of Industrial Engineering, Iran University of Science \& Technology, Tehran 1684613114, Iran. ${ }^{3}$ Faculty of Geographical Sciences and Planning, Isfahan University, Isfahan, Iran.

Received: 7 October 2019 Accepted: 5 March 2021

Published online: 17 March 2021

\section{References}

1. Miles I, Keenan M (2002) Practical guide to regional foresight in the UK. European Commission

2. Garavan TN, Siikaniemi L (2012) Information pathways for the competence foresight mechanism in talent management framework. Eur J Train Dev 36(1):46-65. https://doi.org/10.1108/03090591211192629

3. M. Gidley J (2017) The future : a very short introduction. Oxford University Press, New York pages $\mathrm{cm}$

4. FOREN (2001) A practical guide to regional foresight. European Commission

5. Gertler MS, Wolfe DA (2004) Local social knowledge management: community actors, institutions and multilevel governance in regional foresight exercises. Futures 36(1):45-65. https://doi.org/10.1016/s0016-32 87(03)00139-3

6. Chen C (2006) CiteSpace II: detecting and visualizing emerging trends and transient patterns in scientific literature. J Am Soc Inf Sci Technol 57(3):359377. https://doi.org/10.1002/asi.20317

7. Zambon I et al (2017) Prefiguring a future city: urban growth, spatial planning and the economic local context in Catalonia. Eur Plan Stud 25(10): 1797-1817. https://doi.org/10.1080/09654313.2017.1344193

8. Kalafatis SE et al (2015) Out of control: how we failed to adapt and suffered the consequences. J Great Lakes Res 41:20-29. https://doi.org/10.1016/j.jglr.2 014.12 .00

9. Dixon T et al (2014) Urban retrofitting: identifying disruptive and sustaining technologies using performative and foresight techniques. Technol Forecast Soc Chang 89:131-144. https://doi.org/10.1016/j.techfore.2013.08.027

10. Foran T et al (2013) Developing detailed foresight narratives: a participatory technique from the Mekong region. Ecol Soc 18(4). https://doi.org/10.5751/ es-05796-180406

11. Eames M et al (2013) City futures: exploring urban retrofit and sustainable transitions. Build Res Inf 41(5):504-516. https://doi.org/10.1080/09613218.2 013.805063

12. Docksai $R$ (2012) Strategic foresight for corporate and regional development. Futurist 46(1):49-50 
13. Mahmud J (2011) City foresight and development planning case study: implementation of scenario planning in formulation of the Bulungan development plan. Futures 43(7):697-706. https://doi.org/10.1016/j.futures.2 011.05.011

14. Leclerc $\mathrm{G}$ et al (2010) Participatory modelling and foresight as an entry point for analyzing extensive livestock systems and territorial co-evolution processes. Cahiers Agricult 19(2):152-159. https://doi.org/10.1684/agr.2010. 0380

15. Hanssen GS, Johnstad T, Klausen JE (2009) Regional foresight, modes of governance and democracy. Eur Plan Stud 17(12):1733-1750. https://doi. org/10.1080/09654310903322272

16. Fuller-Love $\mathrm{N}$ et al (2006) Scenario analysis and regional economic development: the case of mid Wales. Eur Urban Reg Stud 13(2):143-149. https://doi.org/10.1177/0969776406062523

17. Puglisi M, Marvin S (2002) Developing urban and regional foresight: exploring capacities and identifying needs in the north west. Futures 34(8): 761-777. https://doi.org/10.1016/s0016-3287(02)00019-8

18. Higdem $U$ (2014) The co-creation of regional futures: facilitating action research in regional foresight. Futures 57:41-50. https://doi.org/10.1016/j. futures.2014.01.006

19. Rodionov D, Rudskaia I, Degtcreva V (2017) Regional foresight as a technology for development of the regional innovation system. In: Soliman KS (ed) Sustainable economic growth, education excellence, and innovation management through vision 2020, vol Vols I-Vii. Int Business Information Management Assoc-lbima, Norristown, pp 2699-2705

20. Ejdys J (2017 of Conference) New silk road - a weak or a strong signal? In: 7th international conference on engineering, project, and production management. Elsevier Science Bv, Amsterdam. https://doi.org/10.1016/j. proeng.2017.03.159

21. Abdoli S, Habib F, Babazadeh M (2018) Making spatial development scenario for south of Bushehr province, Iran, based on strategic foresight. Environ Dev Sustain 20(3):1293-1309. https://doi.org/10.1007/s10668-017-9940-x

22. Benedicto-Royuela J, Buckingham S, Eames M (2018) Transitions to sustainability in small islands: combining foresight scenarios with multi-criteria analysis to develop viable sustainability strategies in an EOR. Int J Sust Dev World 25(8):730-738. https://doi.org/10.1080/13504509.2018.1483442

23. Florian V, Neagu G (2015 of Conference) Romanian contribution to the evaluation of a regional foresight exercise using the goal-question-metric method. In: Proceedings of the 9th international management conference: management and innovation for competitive advantage. Editura Ase, Bucuresti

24. Truffer B et al (2010) Local strategic planning processes and sustainability transitions in infrastructure sectors. Environ Policy Gov 20(4):258-269. https://doi.org/10.1002/eet.550

25. Stoermer E et al (2009) The exploratory analysis of trade-offs in strategic planning: lessons from regional infrastructure foresight. Technol Forecast Soc Chang 76(9):1150-1162. https://doi.org/10.1016/j.techfore.2009.07.008

26. Dufva M, Konnola T, Koivisto R (2015) Multi-layered foresight: lessons from regional foresight in Chile. Futures 73:100-111. https://doi.org/10.1016/j. futures.2015.08.010

27. Stratigea A, Giaoutzi M (2012) Linking global to regional scenarios in foresight. Futures 44(10):847-859. https://doi.org/10.1016/j.futures.2012.09.003

28. Hilbert M, Miles I, Othmer J (2009) Foresight tools for participative policymaking in inter-governmental processes in developing countries: lessons learned from the eLAC policy priorities Delphi. Technol Forecast Soc Chang 76(7):880-896. https://doi.org/10.1016/j.techfore.2009.01.001

29. Nasir GR et al (2019 of Conference) Predictive models and scenarios of economic development of the region. In: Economic and social development. Varazdin Development \& Entrepreneurship Agency, Varazdin

30. Carayannis EG, Meissner D, Edelkina A (2017) Targeted innovation policy and practice intelligence (TIP2E): concepts and implications for theory policy and practice. J Technol Transfer 42(3):460-484. https://doi.org/10.1 007/s10961-015-9433-8

31. Battistella C, Pillon R (2016) Foresight for regional policy: technological and regional fit. Foresight 18(2):93-116. https://doi.org/10.1108/fs-09-2014-0058

32. Dorr A (2016) Technology blindness and temporal imprecision: rethinking the long term in an era of accelerating technological change. Foresight 18(4):391-413. https://doi.org/10.1108/fs-11-2015-0049

33. Spiess $\mathrm{H}$ et al (2015) Future acceptance of wind energy production: exploring future local acceptance of wind energy production in a Swiss alpine region. Technol Forecast Soc Chang 101:263-274. https://doi.org/10.1 016/j.techfore.2015.06.042

34. Romanova OGA, Sirotin DV (2015) New technological shape of basic branches of RF industrial regions. Econ Soc Changes-Facts Trends Forec 41(5):27-43. https://doi.org/10.15838/esc/2015.5.41.2

35. Vecchiato R, Roveda C (2014) Foresight for public procurement and regional innovation policy: the case of Lombardy. Res Policy 43(2):438-450. https:// doi.org/10.1016/j.respol.2013.11.003

36. Koennoelae T, Salo A, Brummer V (2011) Foresight for European coordination: developing national priorities for the forest-based sector technology platform. Int J Technol Manag 54(4):438-459. https://doi.org/1 0.1504/ijtm.2011.041583

37. Glod F, Duprel C, Keenan M (2009) Foresight for science and technology priority setting in a small country: the case of Luxembourg. Tech Anal Strat Manag 21(8):933-951. https://doi.org/10.1080/09537320903262298

38. Uotila T, Ahlqvist T (2008) Linking technology foresight and regional innovation activities: network facilitating innovation policy in Lahti region. Finland Eur Plan Stud 16(10):1423-1443. https://doi.org/10.1080/0965431 0802420144

39. Harper JC, Georghiou L (2005) Foresight in innovation policy: shared visions for a science park and business - university links in a city region. Tech Anal Strat Manag 17(2):147-160. https://doi.org/10.1080/09537320500088716

40. Uotila T, Melkas H, Harmaakorpi V (2005) Incorporating futures research into regional knowledge creation and management. Futures 37(8):849-866. https://doi.org/10.1016/j.futures.2005.01.001

41. Belis-Bergouignan MC, Lung Y, Heraud JA (2001) Public foresight exercises at an intermediate level: the French national programs and the experience of Bordeaux. Int J Technol Manag 21(7-8):726-738. https://doi.org/10.1504/ IJTM.2001.002946

42. Saritas O, Taymaz E, Tumer T (2007) Vision 2023: Turkey's national technology foresight program: a contextualist analysis and discussion. Technol Forecast Soc Chang 74(8):1374-1393. https://doi.org/10.1016/j. techfore.2006.07.005

43. Nazarko J et al (2017 of Conference) Structural analysis as an instrument for identification of critical drivers of technology development. In: 7th international conference on engineering, project, and production management. Elsevier Science Bv, Amsterdam. https://doi.org/10.1016/j. proeng.2017.03.137

44. Bassani G, Minola T, Vismara S (2016) In: Audretsch D et al (eds) Technology foresight for regional economies: a how-to-do guide. University evolution, entrepreneurial activity and regional competitiveness, vol 32. Springer, New York, pp 385-392

45. Kononiuk A, Magruk A (2015 of Conference) Wild cards in polish foresight practice. In: 20th international scientific conference - economics and management 2015. Elsevier Science Bv, Amsterdam. https://doi.org/10.1016/ j.sbspro.2015.11.510

46. Rudskaia I (2017) Regional innovation foresights: drivers and barriers for development. In: Soliman KS (ed) Vision 2020: sustainable economic development, innovation management, and global growth, vol I-Ix. Int Business Information Management Assoc-lbima, Norristown, pp 889-903

47. Lu XQ (2008) Technology foresight and regional industry technology development. In: Proceedings of Hangzhou conference on Management of Technology. Zhejiang Gongshang Univ Press, Hangzhou

48. Li HL, Wang R (2006) Construct technology foresight system for regional decision maker - case study from Wuhan City, China. In: Zhang H, Zhao RM Chen $L$ (eds) Proceedings of the 2006 international conference on management science and engineering. Orient Acad Forum, Marrickville, pp 131-135

49. Matveeva MV, Kaluzhnova NY, Peshkov AV (2018 of Conference) Foresight technology to stimulate innovative activity: opportunities and restrictions. In: Rptss 2018 - international conference on research paradigms transformation in social sciences. Future Acad, Nicosia. https://doi.org/10.154 05/epsbs.2018.12.95

50. Wyrwicka MK, Erdeli O (2018) Strategic foresight as the methodology of preparing innovation activities. Market Manage Innov (2):339-350. https:// doi.org/10.21272/mmi.2018.2-26

51. Pombo-Juarez $L$ et al (2017) Wiring up multiple layers of innovation ecosystems: contemplations from personal health systems foresight. Technol Forecast Soc Chang 115:278-288. https://doi.org/10.1016/j. techfore.2016.04.018 
52. Keller J, Markmann C, von der Gracht HA (2015) Foresight support systems to facilitate regional innovations: a conceptualization case for a German logistics cluster. Technol Forecast Soc Chang 97:15-28. https://doi.org/10.1 016/j.techfore.2013.12.031

53. Ahlqvist T et al (2014) Strategic roadmapping as a policy tool for meso-level industrial transformation: the case of cellulosic fibre value chain in the green triangle, South Australia. Global perspectives on achieving success in high and low cost operating. Environments:172-207. https://doi.org/10.401 8/978-1-4666-5828-8.ch007

54. Toetzer T, Sedlacek S, Knoflacher M (2011) Designing the future-a reflection of a transdisciplinary case study in Austria. Futures 43(8):840-852. https:// doi.org/10.1016/j.futures.2011.05.026

55. Bergez J-E et al (2011) Participatory foresight analysis of the cash crop sector at the regional level: case study from southwestern France. Reg Environ Chang 11(4):951-961. https://doi.org/10.1007/s10113-011-0232-y

56. Frykfors C-O, Jonsson $\mathrm{H}$ (2010) Reframing the multilevel triple helix in a regional innovation system: a case of systemic foresight and regimes in renewal of Skane's food industry. Tech Anal Strat Manag 22(7):819-829. https://doi.org/10.1080/09537325.2010.511145

57. Sorokin DE, Sharafutdinov VN, Onishchenko EV (2017) On the problems of strategic development of tourism in the regions of Russia (case of the Krasnodar region and the Resort City of Sochi). Ekonomika Regiona-Econ Reg 13(3):764-776. https://doi.org/10.17059/2017-3-10

58. Szpilko D (2016) NCRR - new foresight research method. In: Simberova I, Milichovsky F, Zizlavsky O (eds) Smart and efficient economy: preparation for the future innovative economy. Brno Univ Technology, Fac Business \& Management, Brno, pp 612-620

59. Prior T et al (2013) Resourcing the future: using foresight in resource governance. Geoforum 44:316-328. https://doi.org/10.1016/j.geoforum.2012.07.009

60. Macedo D, Mori R Jr, Mizusaki AMP (2017) Sustainability strategies for dimension stones industry based on northwest region of Espirito Santo state. Brazil Resour Pol 52:207-216. https:/doi.org/10.1016/j.resourpol.2017.03.005

61. Kivinen M, Pokki J, Markovaara-Koivisto M (2018) Discovered and undiscovered mineral resources: evolving accounts and future prospects of minerals in Finland. Miner Econ 31(3):301-317. https://doi.org/10.1007/s13 563-017-0131-x

62. Roveda C, Vecchiato $R$ (2008) Foresight and innovation in the context of industrial clusters: the case of some Italian districts. Technol Forecast Soc Chang 75(6):817-833. https://doi.org/10.1016/j.techfore.2008.03.004

63. Piirainen KA, Tanner AN, Alkaersig L (2017) Regional foresight and dynamics of smart specialization: a typology of regional diversification patterns. Technol Forecast Soc Chang 115:289-300. https://doi.org/10.1016/j. techfore.2016.06.027

64. Fabbri E (2016) Strategic planning and foresight: the case of smart specialisation strategy in Tuscany. Foresight 18(5):491-508. https://doi.org/1 0.1108/fs-06-2015-0036

65. Sacio-Szymanska A et al (2016) The future of business in Visegrad region. Eur J Fut Res 4(1). https://doi.org/10.1007/s40309-016-0103-3

66. Capello R, Caragliu A, Fratesi U (2015) Global trends and the economic crisis: future alternative European growth strategies. Technol Forecast Soc Chang 98:120-136. https://doi.org/10.1016/j.techfore.2015.06.005

67. Schwerdtner $W$ et al (2015) Regional open innovation roadmapping: a new framework for innovation-based regional development. Sustainability 7(3): 2301-2321. https://doi.org/10.3390/su7032301

68. Novaky E, Tyukodi G (2010) The responsibility of futurists in strategic foresight - Hungarian examples. Technol Forecast Soc Chang 77(9):15461549. https://doi.org/10.1016/j.techfore.2010.06.013

69. Van Leemput M (2010) Foresight in the Brussels capital region. Futures 42(4):370-379. https://doi.org/10.1016/j.futures.2009.11.022

70. Harmaakorpi V, Uotila T (2006) Building regional visionary capability. Futures research in resource-based regional development. Technol Forecast Soc Chang 73(7):778-792. https://doi.org/10.1016/j.techfore.2005.09.003

71. Desmet K (2000) A perfect foresight model of regional development and skill specialization. Reg Sci Urban Econ 30(2):221-242.https://doi.org/10.101 6/s0166-0462(99)00037-x

72. Kononiuk A, Sacio-Szymanska A (2015) Assessing the maturity level of foresight in polish companies-a regional perspective. Eur J Fut Res 3(1). https://doi.org/10.1007/s40309-015-0082-9

73. Milshina Y, Vishnevskiy K (2018) Potentials of collaborative foresight for SMEs. Tech Anal Strat Manag 30(6):701-717. https://doi.org/10.1080/0953732 5.2017 .1406906
74. Al-Saleh YM et al (2012) Carbon capture, utilisation and storage scenarios for the Gulf cooperation council region: a Delphi-based foresight study. Futures 44(1):105-115. https://doi.org/10.1016/j.futures.2011.09.002

75. Ropuszynska-Surma E, Szalbierz Z, Borgosz-Koczwara M, Wyłomańska A (2011) Regional energy strategy on the basis of the foresight study. Rynek Energii 93:151-156

76. Ropuszynska-Surma E, Weglarz M, Wylomanska A (2011) The foresight study as a tool of the regional energy policy planning. Przeglad Elektrotechniczny 87(9A):226-229

77. Ropuszynska-Surma E, Weglarz M, Wylomanska A (2010) Energy development strategy on the lower Silesia by using the foresight methods. Rynek Energii 6:105-107

78. Guel T et al (2009) An energy-economic scenario analysis of alternative fuels for personal transport using the global multi-regional MARKAL model (GMM). Energy 34(10):1423-1437. https://doi.org/10.1016/j.energy.2009.04.01 0

79. Andersen PD et al (2018) The North Sea offshore wind service industry: status, perspectives and a joint action plan. Renew Sustain Energy Rev 81: 2672-2683. https://doi.org/10.1016/j.rser.2017.06.073

80. Ropuszynska-Surma E, Weglarz M (2011) Waste management for energy purposes in the energy strategy for lower Silesia. Rynek Energii 4:37-42

81. Auffermann B, Allievi $F$ (2010) Changing energy production, emerging technologies and regional security. Ener Options Impact Reg Secur:363-377. https://doi.org/10.1007/978-90-481-9565-7_20

82. Shkrobot M, Ropuszynska-Surma E (2018) Polish and Ukrainian foresight into the directions for the innovation of power plants. Oper Res Decis 28(4):4770. https://doi.org/10.5277/ord180404

83. Myllyla Y, Kaivo-oja J, Juga J (2016) Strong prospective trends in the Arctic and future opportunities in logistics. Polar Geogr 39(3):145-164. https://doi. org/10.1080/1088937x.2016.1184723

84. Mora O et al (2014) Using scenarios for forest adaptation to climate change: a foresight study of the Landes de Gascogne Forest 2050. Ann For Sci 71(3): 313-324. https://doi.org/10.1007/s13595-013-0336-2

85. Mokrech M, Nicholls RJ, Dawson RJ (2012) Scenarios of future built environment for coastal risk assessment of climate change using a GISbased multicriteria analysis. Environ Plan B-Plan Design 39(1):120-136. https://doi.org/10.1068/b36077

86. Odada EO, Ochola WO, Olago DO (2009) Understanding future ecosystem changes in Lake Victoria basin using participatory local scenarios. Afr J Ecol 47:147-153

87. Stoermer E (2008) Greening as strategic development in industrial change why companies participate in eco-networks. Geoforum 39(1):32-47. https:// doi.org/10.1016/j.geoforum.2006.12.001

88. Myllyla Y, Kaivo-oja J (2015) Integrating Delphi methodology to some classical concepts of the Boston consulting group framework: Arctic maritime technology BCG Delphi foresight-a pilot study from Finland. Eur J Fut Res 3(1). https://doi.org/10.1007/s40309-014-0060-7

89. Sotirov $\mathrm{M}$ et al (2017) Do forest policy actors learn through forwardthinking? Conflict and cooperation relating to the past, present and futures of sustainable forest management in Germany. Forest Policy Econ 85:256268. https://doi.org/10.1016/j.forpol.2016.11.011

90. Newlands NK (2018) Model-based forecasting of agricultural crop disease risk at the regional scale, integrating airborne inoculum, environmental, and satellit-based monitoring data. Front Environ Sci 6:16. https://doi.org/10.33 89/fenvs.2078.00063

91. Serrao-Neumann S, Choy DL (2018) In: Neumann SS, Coudrain A, Coulter L (eds) Uncertainty and future planning: the use of scenario planning for climate change adaptation planning and decision, in communicating climate change information for decision-making. Springer International Publishing Ag, Cham, pp 79-90

92. Richard-Ferroudji A et al (2016) The DIALAQ project on sustainable groundwater management: a transdisciplinary and transcultural approach to participatory foresight. Curr Opin Environ Sustain 20:56-60. https://doi.org/1 0.1016/j.cosust.2016.06.002

93. Graveline N et al (2014) Coping with urban \& agriculture water demand uncertainty in water management plan design: the interest of participatory scenario analysis. Water Resour Manag 28(10):3075-3093. https://doi.org/1 0.1007/s11269-014-0656-5

94. Graveline $\mathrm{N}$ et al (2012) Impact of farming on water resources: assessing uncertainty with Monte Carlo simulations in a global change context. Agr Syst 108:29-41. https://doi.org/10.1016/j.agsy.2012.01.002 
95. Lienert J, Monstadt J, Truffer B (2006) Future scenarios for a sustainable water sector: a case study from Switzerland. Environ Sci Technol 40(2):436442. https://doi.org/10.1021/es0514139

96. Stratigea A, Katsoni V (2015) A strategic policy scenario analysis framework for the sustainable tourist development of peripheral small island areas the case of Lefkada-Greece Island. Eur J Fut Res 3(1). https://doi.org/10.1 007/s40309-015-0063-z

97. Riensche M et al (2015) Tourism at Costalegre, Mexico: an ecosystem services-based exploration of current challenges and alternative futures. Futures 66:70-84. https://doi.org/10.1016/j.futures.2014.12.012

98. Borodako K (2014) Key foresight attributes of tourism companies in the City of Krakow and the region. Int J Tour Res 16(3):282-290. https://doi.org/10.1 002/jtr.1927

99. Gardiner S, Grace D, King C (2014) The generation effect: the future of domestic tourism in Australia. J Travel Res 53(6):705-720. https://doi.org/1 $0.1177 / 0047287514530810$

100. de Lattre-Gasquet M, Treyer S (2016) Agrimonde and agrimonde-terra: foresight approaches compared. Ids Bull-Inst Dev Stud 47(4):37-53. https:// doi.org/10.19088/1968-2016.154

101. Sundbo J (2016) Food scenarios 2025: drivers of change between global and regional. Futures 83:75-87. https://doi.org/10.1016/j.futures.2016.03.003

102. Ronzon T, Paillard S, Chemineau P (2013) Elements for a foresight debate on food sustainability. Food system sustainability: insights from Dualine, pp 176-197

103. Lestrelin G et al (2017) Collaborative landscape research in Reunion Island: using spatial modelling and simulation to support territorial foresight and urban planning. Appl Geogr 78:66-77. https://doi.org/10.1016/j.apgeog.201 6.11 .003

104. Dwyer J (2011) UK land use futures: policy influence and challenges for the coming decades. Land Use Policy 28(4):674-683. https://doi.org/10.1016/j.la ndusepol.2010.12.002

105. Verkerk PJ et al (2018) Identifying pathways to visions of future land use in Europe. Reg Environ Chang 18(3):817-830. https://doi.org/10.1007/s10113016-1055-7

106. Botta A et al (2009) Integration of multi-scale stakes in governance by applying companion modelling to land use foresight. In: Anderssen RS, Braddock RD, Newham LTH (eds) 18th world Imacs congress and Modsim09 international congress on Modelling and simulation: interfacing Modelling and simulation with mathematical and computational sciences. Modelling \& Simulation Soc Australia \& New Zealand Inc, Christchurch, pp 4395-4401

107. Capello R, Caragliu A (2016) After crisis scenarios for Europe: alternative evolutions of structural adjustments. Camb J Reg Econ Soc 9(1):81-101. https://doi.org/10.1093/cjres/rsv023

108. Lenton TM (2013) What early warning systems are there for environmental shocks? Environ Sci Policy 27:S60-S75. https://doi.org/10.1016/j.envsci.2012 06.011

109. Eames $M$ et al (2006) Negotiating contested visions and place-specific expectations of the hydrogen economy. Tech Anal Strat Manag 18(3-4):361374. https://doi.org/10.1080/09537320600777127

110. Inayatullah S (2011) City futures in transformation: emerging issues and case studies. Futures 43(7):654-661. https://doi.org/10.1016/j.futures.2011.05.006

111. Hodson M, Marvin S (2012) Mediating low-carbon urban transitions? Forms of organization, knowledge and action. Eur Plan Stud 20(3):421-439. https:// doi.org/10.1080/09654313.2012.651804

112. Gaffikin F, Sterrett K (2006) New visions for old cities: the role of visioning in planning. Plan Theory Pract 7(2):159-178. https://doi.org/10.1080/146493 50600673070

113. Phdungsilp A (2011) Futures studies' backcasting method used for strategic sustainable city planning. Futures 43(7):707-714. https://doi.org/10.1016/j. futures.2011.05.012

114. Quist J, Vergragt P (2006) Past and future of backcasting: the shift to stakeholder participation and a proposal for a methodological framework. Futures 38(9):1027-1045. https://doi.org/10.1016/j.futures.2006.02.010

115. Cuhls K (2003) From forecasting to foresight processes? New participative foresight activities in Germany. J Forecast 22(2-3):93-111. https://doi.org/1 $0.1002 /$ for 848

116. Eriksson EA, Weber KM (2008) Adaptive foresight: navigating the complex landscape of policy strategies. Technol Forecast Soc Chang 75(4):462-482. https://doi.org/10.1016/j.techfore.2008.02.006

117. Doloreux D (2002) What we should know about regional systems of innovation. Technol Soc. https://doi.org/10.1016/S0160-791X(02)00007-6
118. Rohrbeck R, Schwarz JO (2013) The value contribution of strategic foresight: insights from an empirical study of large European companies. Technol Forecast Soc Chang 80(8):1593-1606. https://doi.org/10.1016/j.techfore.2013. 01.004

119. Rohrbeck R, Gemünden HG (2011) Corporate foresight: its three roles in enhancing the innovation capacity of a firm. Technol Forecast Soc Chang 78(2):231-243. https://doi.org/10.1016/j.techfore.2010.06.019

120. Miles I (2010) The development of technology foresight: a review. Technol Forecast Soc Chang 77(9):1448-1456. https://doi.org/10.1016/j.techfore.2010. 07.016

121. Havas A (2010) The impact of foresight on innovation policy-making: recent experiences and future perspectives. Res Eval. https://doi.org/10.3152/09582 $0210 \times 510133$

122. Da Costa $\mathrm{O}$ et al (2008) The impact of foresight on policy-making: insights from the FORLEARN mutual learning process. Tech Anal Strat Manag 20(3): 369-387. https://doi.org/10.1080/09537320802000146

123. Schoen A et al (2011) Tailoring foresight to field specificities. Futures 43(3): 232-242. https://doi.org/10.1016/j.futures.2010.11.002

124. Andersen PD et al (2014) Sectoral innovation system foresight in practice: Nordic facilities management foresight. Futures 61:33-44. https://doi.org/1 0.1016/j.futures.2014.04.012

125. Cagnin C, Amanatidou E, Keenan M (2012) Orienting European innovation systems towards grand challenges and the roles that FTA can play. Sci Public Policy 39(2):140-152. https://doi.org/10.1093/scipol/scs014

126. Andersen AD, Andersen PD (2014) Innovation system foresight. Technol Forecast Soc Chang 88:276-286. https://doi.org/10.1016/j.techfore.2014.06.01 6.

127. Puglisi M (2002) Developing urban and regional foresight: exploring capacities and identifying needs in the north west. Futures. https://doi.org/1 0.1016/S0016-3287(02)00019-8

128. Koschatzky K (2005) Foresight as a governance concept at the interface between global challenges and regional innovation potentials. Eur Plan Stud 13(4):619-639. https://doi.org/10.1080/09654310500107365

129. Georghiou L (2008) In: Georghiou L et al (eds) The handbook of technology foresight: concepts and practice, Prime series on research and innovation policy. Edward Elgar, Cheltenham

\section{Publisher's Note}

Springer Nature remains neutral with regard to jurisdictional claims in published maps and institutional affiliations.

\section{Submit your manuscript to a SpringerOpen ${ }^{\circ}$ journal and benefit from:}

- Convenient online submission

- Rigorous peer review

- Open access: articles freely available online

- High visibility within the field

- Retaining the copyright to your article

Submit your next manuscript at $>$ springeropen.com 